\title{
Who Needs Leadership? Social Problems, Change, and Education Futures
}

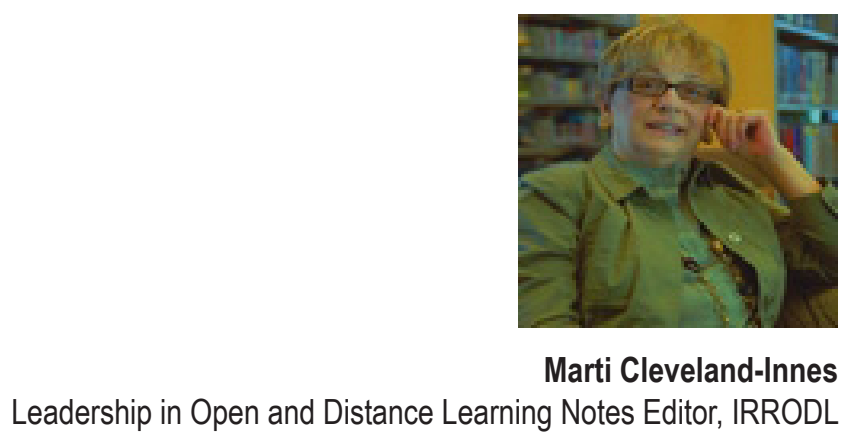

We are all impacted by leadership; we all have the opportunity to take the lead; hence, we all need leadership and an understanding of this complex social phenomenon. Leadership speaks to a ubiquitous, identifiable set of human activities that support and assist, particularly in relation to change. Currently, changes in many things, including technology, "constitutes [sic] the most consequential set of changes in society since the late nineteenth century, when the nation went from a largely domestic, rural, agrarian mode of living to an industrial, international, and urban economy" (Keller, 2008, Preface xi). For education "this set of circumstances is going to force all academic enterprises to rethink their place and purpose not just in philosophical terms but in very pragmatic ways as well" (Beaudoin, 2003, p. 520). These philosophical and pragmatic changes also affect leadership practice and the role of leader.

Pervasive technology and notable socioeconomic restructuring have changed our society. This change has made it increasingly difficult for education to operate in insular ways; attention to changing demographics, global economies, new social mores, and new information and communication technologies is vital (Keller, 2008). The reach of technology seems limitless and has already changed education in "the way we organize ourselves, our policies, our culture, what faculty do, the way we work, and those we serve" (Ikenberry, 2001, Forward). Change in education to accommodate broader societal change embodies new ways of thinking about access to education, economic issues, accountability, technology in the teaching-learning process, and, most importantly, leadership.

When we speak of leadership in education, we are speaking of leadership in public institutions that are designed to serve the greater good. It is not possible to provide effective leadership without an understanding of the purpose of education and its role in society. Education is fundamentally characterized by a quest for improving the human condition. It is to overcome social and economic challenges, resolve inequities, promote societal power and prowess, and allow for individual development. According to Schofield (1999), educa- 
tion is a place where people develop according to their unique needs and potential; one of the best means of achieving greater social equality is to allow every individual to develop to their full potential.

Leadership is required to ensure education institutions are shaped to allow for such individualization. How will we take strides to make things happen in education - who takes the lead, doing what? Notions of defined leadership roles and dutiful followers come to mind. In the postmodern turn of society, more complexity emerges. Here, leadership is founded in service to a collective vision of a dynamic, responsive organization. Here, leadership is built on humility rather than hubris. Here, leadership fosters collaboration rather than competition "on a foundation of generativity and generosity rather than stagnation and resentment” (Berquist, 2010, Challenges).

How do we move these notions of postmodernity to education? For Bloland (2005), the newly emerging society requires a university that takes advantage of the democratization and contestation of knowledge and promotes technological and cross-cultural citizenship. The higher education leader of the $21^{\text {st }}$ century will exhibit strong character, well-developed personal skills, and the ability to create and communicate vision (Garrison \& Vaughan 2008). In addition to these personal traits, this new leader will be willing and able to 1) manage change and innovation; 2) listen to and assist stakeholders, maintaining and enhancing relationships between the institution and relevant partners; 3) embrace the realities of network environments; and 4) ensure transformation to a new model of teaching and learning (Cleveland-Innes \& Sangra, 2011).

What about traditional theories of leadership? These theories have largely focused on hierarchical relationships where there is a clearly defined power structure with a minority of individuals in leadership roles and a great number of individuals serving in the follower role (Avolio, Walumbwa, \& Weber, 2009). According to Gronn (2003), multiple issues in our traditional conceptualization of leadership need to be resolved:

... difficulties in distinguishing leadership from management; tensions between leadership, influence and power; the potential redundancy of leadership in the face of possible substitute factors; leader-followership's presumption of a division of labour; the prevailing myth of exceptionality; and disciplined subjectivity achieved through emergent forms of designer leadership. Embedded in each of these criticisms is the claim that if leadership is to retain its conceptual and practical utility, then it has to be reconstituted in a distributed, as opposed to a focused, form. (p. 267)

These are issues for education leadership in particular. Highly trained faculty and staff in education institutions exist in an environment of self-governance. Respectful dialogue and distribution of decision-making is expected. In this arena, leadership must be dispersed 
beyond central administration to include the rank and file, "reconstituted in a distributed, as opposed to a focused, form" (Gronn, 2003, 267). Relationships must be collaborative and communicative if change is going to be addressed (Cleveland-Innes, Emes, \& Ellard 2001).

The theory of collaborative, distributed leadership takes on increased meaning when we see it in reference to developing virtual learning communities (Bligh, Pearce, \& Kohles, 2006; Paulsen, 2007). The idea of a shared, distributed lead is contemporary - it is "a dynamic interactive process among individuals in groups for which the objective is to lead one another to the achievement of group, or organizational goals, or both" (Pearce \& Conger, 2003, p. 1).

There are some great examples where a social issue is raised, education is determined to be one remedy, and leadership ensues to implement the education innovation. In this case, leadership is often seen as problem-based, solution-centered, ethical, shared and distributed, working continuously toward the greatest good for the greatest number, beyond the reproduction of the status quo toward increased equity. The Leadership in Open and Distance Learning Notes (LODLN) section in IRRODL provides the opportunity to debate potential principles and premises in support of leadership in the new education, education of high quality that is accessible and socially meaningful.

\section{References}

Avolio, B., Walumbwa, F., \& Weber, T. (2009). Leadership: Current theories, research and future directions. Annual Review of Psychology, 6o, 421-449.

Beaudoin, M. (2003). Distance education leadership for the new century. Online Journal of Distance Learning Administration, 6(2). Retrieved from http://www.westga. edu/\%7Edistance/ojdla/summer62/beaudoin62.html

Bergquist, W. (2010). Postmodern leadership. Retrieved from http://williambergquist. wordpress.com/

Bligh, M.C., Pearce, C.L., \& Kohles, J.C. (2006), The importance of self- and shared leadership in team based knowledge work. Journal of Managerial Psychology, 4, 21, 296-318. Retrieved from http://www.cgu.edu/include/Bligh\%20Pearce\%20 Kohles\%202006.pdf.

Bloland, H. G. (2005). Whatever happened to postmodernism in higher education?: No requiem in the new millennium. The Journal of Higher Education, 76(2), 121-50.

Cleveland-Innes, M., \& Sangra, A. (2010). Leadership in a new era of higher distance education. In M. Cleveland-Innes \& D.R. Garrison (Eds.), Introduction to distance learning: Understanding teaching and learning in a new era. New York: Routledge Publishing Inc.

Cleveland-Innes, M., Emes, C., \& Ellard, J. (2001). On being a social change agent in a re- 
luctant collegial environment. Planning in Higher Education, 29, 25-33.

Garrison, D. R., \& Vaughan, N.D. (2008). Blended learning in higher education. San Francisco: Jossey-Bass.

Gronn, P. (2003). Leadership: Who needs it? School Leadership and Management, 23(3), 267-290.

Ickenberry, S. (2001). Forward. In C. Latchem \& D. Hanna (Eds.), Leadership for $21^{\text {st }}$ century learning: Global perspectives from educational perspectives. Sterling, VA.: Stylus Publishing.

Keller, G. (2008). Higher education and the new society. Maryland: John Hopkins University Press.

Schofield,K.(1999). Thepurposesofeducation.QueenslandStateEducation:2010.Retrieved from http://education.qld.gov.au/corporate/qse2010/pdf/purposesofed3.pdf.

\section{Athabasca University $\mathbf{A}$}

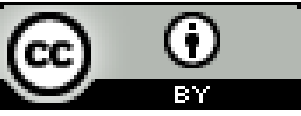

